\title{
Advances in nutritional manipulation rumen functions of surfactants
}

\author{
Y. Liu ${ }^{1,3,4}$, L.M.Camacho ${ }^{2}$, S. Tang ${ }^{1}$, Z.Tan ${ }^{1 *}$ and A.Z.M. Salem ${ }^{3,5^{*}}$ \\ ${ }^{1}$ Key Laboratory of Agro-ecological Processes in Subtropical Region, Institute of Subtropical Agricultural, the Chinese \\ Academy of Sciences, Hunan Changsha 410125,P.R. China. \\ ${ }^{2}$ Facultad de Medicina Veterinaria y Zootecnia, Guerrero, México. \\ ${ }^{3}$ Graduate University of Chinese Academy of Sciences, Beijing 100049, P.R. China. \\ ${ }^{4}$ Facultad de Medicina Veterinaria y Zootecnia, Universidad Autónoma del Estado de México, México. \\ ${ }^{5}$ Faculty of Agriculture (El-Shatby), Alexandria University, Egypt.
}

Accepted 25 February, 2013

\begin{abstract}
Surfactant, including chemical surface active agent and biosurfactants, as a new type of feed additive applied in ruminant production, can effectively improve the degradability of roughages in the rumen and productivity of ruminants by increasing the emulsification of ruminal liquid, the number of ruminal microorganisms and the activity of ruminal endogenous enzymes secreted by ruminal microbes; and changing the contents and proportion of volatile fatty acids. In future, the preparation, purification, industrial production and nutritional mechanism of biosurfactants should be the focuses in the fields of ruminant nutrition.
\end{abstract}

Key words: Surfactant, ruminal microorganisms, nutritional manipulation.

\section{INTRODUCTION}

In recent years, surfactants are more and more widely used in the fields of spinning, medicine, washing, cosmetic, food and feed additives. The advantages of surfactants have fueled the growth of the surfactant market to the annual global production of 13 million metric tons in 2008 and annual global sales of $\$ 24.33$ billion in 2009 , nearly $2 \%$ up from previous years, the market shares are expected to experience quite healthy growth by $2.8 \%$ annually to 2012 and by $3.5 \sim 4 \%$ thereafter (Reznik et al., 2010). At present, almost all of the surfactants are synthetic compounds, while the biosurfactants only have a tiny fraction of market share. However, compared with the synthetic surfactants, the interest in biosurfactants has been steadily increasing in recent years because of their functional diversity, excellent biocompatibility, biological degradability, environmentally friendly nature and relative ly nontoxicity. In the field of animal nutrition, some articles reported that the addition of surfactants to basal diets improved microbial activity, changed the pattern of rumen fermentation and improved feed utilization efficiency (Lee et al., 2004; Cong et al., 2009; Yuan et al., 2010). The extensive study and application of microbial biosurfactants are restricted by high costs of technology and production process, but both microbial biosurfactants and synthetic surfactants are paid an equal attention to the basic and application research of animal nutrition. Therefore, this article addresses the classification, functional mechanisms and nutritional manipulation of rumen function of synthetic surfactants (especially nonionic surfactant) and biosurfactants, aims to offer a valuable reference for sur- 
factant add to the basal diet as feed additives.

\section{Classification of surfactants}

Surfactants, which are the blend of surface active agents (Rosen and Kungjappu, 2012), are compounds that lower the surface tension of solution, oil or solid-water interfaces at low concentration, and play an important role in emulsifying, foaming, cleaning, wetting, dispersing and solubilizing. Surfactants are high molecular weight organic compounds that are amphiphilic copolymers; containing both hydrophobic and hydrophilic groups (Sperling and Parak, 2010). The hydrophilic group is a polar group including $-\mathrm{COOH},-\mathrm{SO}_{3} \mathrm{H},-\mathrm{SO}_{4} \mathrm{H},-\mathrm{NH}_{4}{ }^{+},-\mathrm{NH}_{2}$ and amine salt as well as $-\mathrm{OH},-\mathrm{CONH}_{2}$ or R-O-R' and so on; the hydrophobic group is a non-polar hydrocarbon chain, consisting of more than 8 carbon atoms. Surfactants are divided into two categories of synthetic surfactants and biosurfactants.

These surface active substances are amphiphilic in nature, having both hydrophilic and hydrophobic domains (group) that allow them to exist preferentially at the interface between polar and non-polar solution. Thus, surfacetants tend to accumulate at interfaces (air-water and oilwater) as well as at air-solid and liquid-solid surfaces. Accumulation of surfactants at interfaces or surfaces results in the reduction of repulsive forces between dissimilar phases and allows the two phases to mix and interact more easily (Holmberg et al., 2003).

\section{Synthetic surfactants}

According to the properties of functional groups, synthetic surfactants are sorted into four classes: Cationic, anionic, zwitterionic and nonionic. A surfactant which dissociates in water and releases cation and anion (or zwitterions) is termed as ionic (cationic, anionic, zwitterionic). On the other hand, a surfactant that cannot release the ion is called as nonionic.

Nonionic surfactants that reduce the surface tension are independent of the dissociated ion, but depend on the polar groups with weak hydrophilicity. The hydrophobic groups of nonionic surfactants are always hydrocarbon chains (example aliphatic series or aromatic series) with 8 18 carbon atoms, whereas the hydrophilic groups are the groups including the hydroxide radical, polyoxyethylene or ammonio, for example the fatty glycerides, sorbic acid, polysorbate and alkyl polyglycosides. At present, the nonionic surfactants with the good biodegradability, low irritation and excellent physicochemical properties have been researched as a popular topic in the field of animal nutrition.

\section{Biosurfactants}

Biosurfactants are synthesized by plants and animals as well as microorganisms. Biosurfactants display important biological activities, including lower toxicity, biodegradebility and effectiveness at a wide range of temperature and pH values (Soberón-Chávez and Maier, 2011; Banat et al., 2010). Biosurfactants are separated into low and high molecular weight compounds, the former contain glycolipid, lipopeptid and phospholipid, and the latter are comprised of the flocculent and granulate complexes of polysaccharide, lipopolysaccharide, protein and lipoprotein. According to their chemical structures, biosurfactants are divided into five categories, including the glycolipid, lipoid, phospholipid, aliphatic acid and polymer of protein and lipid, the details is shown in Table 1.

Because the leading trend towards using environmental friendly technologies has enhanced the search work for biodegradable compounds of natural origin. And compared to the synthetic surfactants, biosurfactants have many advantages including low toxicity, high efficiency, low irritation, environmental friendliness and good digestibility, besides reducing the surface tension, stabilizing the emulsification property and increasing the foaming characteristics. Therefore, biosurfactants are the natural choice for such processes as they have a host of advantages over synthetic surfactants.

\section{NUTRITIONAL MANIPULATION FUNCTIONS OF NONIONIC SURFACTANTS FOR RUMINANTS}

At present, nonionic surfactants (NIS), which are applied to the feed additives of livestock, consist mainly of Tween-60 (polyethylene glycol sorbitan monostearate), Tween-80 (polyoxyethylene sorbitan monooleate), SOLFA-850 (mainly composed of dehydrated sorbitan trioleate, chemical composition of malic acid and deionized water), APG ( alkyl polygucoside), and sorbitan trioleate.

\section{Tween series}

The empirical formula of Tween-60 is $\mathrm{C}_{24} \mathrm{H}_{46} \mathrm{O}_{6} \cdot\left(\mathrm{C}_{2} \mathrm{H}_{4} \mathrm{O}\right) \mathrm{n}$, and its water solubility is $100 \mathrm{~g} / \mathrm{L}$. The empirical formula of Tween-80 is $\mathrm{C}_{64} \mathrm{H}_{124} \mathrm{O}_{26}$, which can easily dissolve in water and organic solvent. The molecular structures of Tween series are shown in Figure 1.

The addition of Tween-60 and Tween- 80 to basal diets mainly influenced the activities of ruminal endogenous enzymes, the population of microorganisms, and the pattern of ruminal fermentation as well as the roughage utilization efficiency. Adding NIS to ruminant diet can observably improve the activities of protease, amylase, CMCase and xylanase (Lee et al., 2004), and can effectively stimulate the cellulase synthase complex of aerobic fungi to release, but have no influence on anaerobic microorganisms (Wittenberger et al., 1978; Gyu-Chul et al., 2009; Chen et al., 2011). The addition of Tween-80 to the culture medium of Corynebacterium matruchotii which can convert Tween-80 to a structural series of polyoxyethylenic acids which replaced corynomycolic acids in the cell wall, are used to form novel series-2A and series-2B glycolipids. 
Table 1. Classification and sources of biosurfactants.

\begin{tabular}{lll}
\hline Classification & Representative product & Strains name \\
\hline Glycolipid & Rhamnolipids & Pseudomonas aeroginosa (Abdel-Mawgoud et al., 2010; Li et al., 2011) \\
& Sophorolipids & Candida (Saerens et al. 2011) \\
& Trehalose lipids & Rhodococcus、Myco-bacterium and \\
& & Arthrobacter (Franzetti et al., 2010; Zaragoza et al., 2009)
\end{tabular}

Amino acids lipid Lipoprotein and Lipopeptide

Bacillus subtilis (Smyth et al., 2010) Pseudomonas fluorescens (de Bruijn and Raaijmakers, 2009; D'Aes et al., 2010) Bacillus pumilus $A$ (Seydlová and Svobodová, 2008)

Fatty acid Glyceride, Fatty alcohol and Wax Corynebacterium (Radmacher et al., 2005)

Phospholipid Phosphatidylcholine Bile acids

High polymer
Lipopolysaccharide complex Protein-polysaccharide compound
Acinetobacter (Käppeli and Finnerty, 1980) Myroides sp, strain SM1 (Maneerat et al., 2005)

Candida lipolytica (Amaral et al., 2006; Rufino et al., 2007) Bacillus (Smyth et al., 2010; Gurjar et al., 1995) Corynebacterium kutscheri (Thavasi et al., 2007)
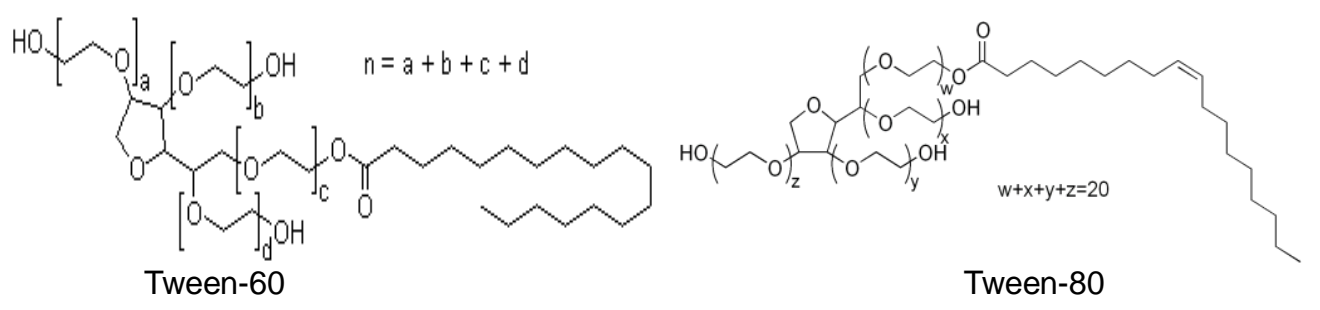

Figure 1. Molecular structures of Tween-60 and Tween-80.

It suggested that the minor changes of permeability on the Corynebacterium cell wall caused by the synthesis of these novel glycolipids may increase the release of intracellular enzymes to the outside of the cell (Wang et al., 2011). A study on the basal diet of Chinese Merino sheep supplemented with $10 \mathrm{~g}$ Tween-60 and Tween-80 has shown that the rumen apparent dry matter and hemicellulose digestibilities as well as the activities of CMCase tended to be improved, and the author suggested that Tween- 80 improved the activities of ruminal CMCase by effectively prohibiting the inactivation of enzymes (Chen et al., 2011). Another study based on addition of Tween60 and Tween- 80 to the diet of dairy cows suggested that maximum accelerations of protease activity with addition of Tween-60 and Tween-80 were 99.2 and $166.8 \%$, respectively. The activity of cellulase was obviously increased, and the adsorption rate and extent of rumen microorganisms to wheat straw was remarkably improved (Kamande et al. 2000). In vitro experiment showed that Tween-80 can not only obviously increased the population of rumen microorganisms, but also improved the activities of xylanase, cellulase, hemicellulase and protease (Kim et al., 2005; Kim et al., 2007; Kumar and Neelam, 2009). In addition, Tween-80 can convert the desmoenzyme to resolvase as well as improve the xylanase, protease, amylase, and glucanase activities (Deng et al., 2005). However, Tween-80 also increased the amylase, protease, cellulase, xylanase (Liu et al., 2011; Zeng et al., 2006) and deaminase (Ganesh Kumar et al., 2008) activities to varying degrees on the monoculture.

Tween also has an influence on the rumen microbial population of the host. A report showed that Tween-80 dramatically enhanced the population of non-cellulolytic bacteria including Ruminobacter amylophilus, Megasphaera elsdenii, Prevotella ruminicola and Selenomonas ruminantium, and significantly increased the growth rate of fungi such as Neocallimastix patriciarum strain 27, Piromyces communis strain 22, Orpinomyces joyonii strain 19-2 and Anaeromyces mucronatus strain 543, but have a minor or no influence on the rumen cellulolytic bacteria including Fibrobacter succinogenes, Ruminococcus albus, Ruminococcus flavefaciens and Butyrivibrio fibrisolvens (Lee et al., 2003). Similar experiment showed that Tween-80 increased the population of rumen microbes from $(7.50 \pm 1.3) \times 10^{9}$ to $(31.0 \pm 4.6) \times 10^{9} \mathrm{cfu} / \mathrm{mL}$ on the verge of four times, which not only improved the popula- 
tion of fungi and protozoa, but also significantly promoted the growth rate of non-cellulolytic bacteria (Lee et al., 2004; Deng et al., 2005).

The Tweens also have been known to exert a number of positive impacts on the fermentation characteristics and feed utilization efficiency. The concentrations of volatile fatty acid (VFA) of jumbuck's rumen liquor were increased with the supplementation of Tween-40,60, and 80, but the ratio of acetic acid and propionic acid were not affected (Chen et al., 2011; Wittenberger et al., 1978). When Tween-60 and 80 were administrated to the rumen of sheep, the dry matter digestibility was increased, but Tween series administration did not affect the rumen fermentation characteristics, $\mathrm{pH}$ value and the population of rumen protozoa. In addition, the digestibility and disappearance rate of rice straw were not affected by the addition of Tween-80 to dairy cattle diets (Lee et al., 2004). Nevertheless, milk production increased $2.5 \sim 3.5 \mathrm{~kg}$ per day by the addition of Tween-80 at $0.2 \%(\mathrm{wt} / \mathrm{wt})$ to the dairy cattle diets (Shelford et al., 1996). Tween-80 as an additive to diets of Hanwoo steers affected rumen $\mathrm{pH}$, total VFA concentration, and digestibility of crude fiber (Kim et al., 2004). The above research results indicated that Tween series as NIS can improve the growth rate of rumen microbes and increase the enzymes activities of rumen microbes; furthermore enhance the feed unitization efficiency and performance by improving the rumen fermentation characteristics.

\section{Alkyl polyglucoside}

Alkyl polyglucoside (APG) is a type of NIS obtained from renewable resources including starch, glucose or natural fatty alcohols. Alkyl polyglucoside have been widely applied in the fields of animal nutrition because of its excellent surface activity, low toxicity, hypo-allergenicity, biodegradability, safety and environmental friendliness (Yuan et al., 2010). APG may improve in vitro dry matter and organic matter disappearance of low quality roughages (Cong et al., 2009). Alkyl polyglucoside has also been shown to increase the concentrations of $\mathrm{NH}_{3}-\mathrm{N}$, total volatile fatty acids and the rate of acetic acid and propionic acid production, and can improve the total tract digestibility of $\mathrm{OM}$ and NDF as well as the duodenal microbial $\mathrm{N}$ flow and efficiency of microbial protein syn-thesis (Yuan et al., 2010). In addition, dietary APG inclu-sion altered amino acid and fatty acids composition of rumen bacteria cytomembrane, which further implied a change in function and survival of rumen bacteria, and decreased the population of Ruminococcus albus (Zeng et al., 2012).

\section{Mechanism}

Nutritional manipulation in ruminants by NIS has been proposed to occur via two mechanisms. The first is through increasing endogenous enzyme release and/or improving the enzyme activities, and the second is through increa- sing the interaction between enzyme and substrate. The first proposed mechanism is disputed. Kim et al. (1982) considered that NIS can fortify the stability of enzymes, and prohibit the denaturalization and deactivation of enzyme during the process of hydrolysis. Other researchers have proposed that the interaction of the hydrophobic group of NIS with ruminal bacteria cell membranes increased the cell membrane fluidity and permeability that may stimulate more endogenous enzyme secretion (Lee et al., 2003 and 2004; Demain, 1968).

NIS are well known to increase the interactions between cellulose degrading enzyme and substrate (Viparelli et al., 2001). Enzymatic hydrolysis of lignocellulosic materials was significantly affected by cellulase adsorption onto the substrates (Tu et al., 2009). Castanon and Wilke (1981) considered that NIS can reduce the adhesion of enzyme to substrate further more reduce the irreversible adsorption of cellulase to roughages. Park et al. (1992) suggested that NIS can release the cellulase from saccharification binding site on the surface of substrate to recover the enzyme activity for hydrolyzing more roughage, or NIS help the enzyme be desorbed from the binding site on the substrate surface after the completion of saccharification at that site. NIS not only can increase the surface area of cellulose accessible to enzyme, but also make the hydrophobic degradation products from lignin and hemicellulose extractable to water (Kurakake et al., 1994). Surfactants that improve conversion of lignocelluloses have been shown to adsorb on roughage surfaces resulting in reduction of unproductive enzyme binding (Börjesson et al., 2007), and the addition of surfactants has been suggested to hinder deactivation of enzymes by exclusion of enzymes from roughages surfaces (Tu et al., 2009), would give more opportunity for cellulase to adsorb onto the surface of roughages (Eriksson et al., 2002; Olsen et al., 2011). In contrast to newspaper substrate, the NISpretreated pure cellulose substrates had a significant effect on digestibility during hydrolysis in the presence of a surfactant, demonstrating that NIS effect on digestibility is highly dependent on substrate type (Kim et al., 2007). Under all circumstances, NIS alters the rumen fermentation by affecting the population of ruminal microbes, but the importance of these species is relied on secretion of complex enzymes (Long and Knapp, 1991; Gashe, 1992; Pardo, 1996).

\section{Nutritional manipulation functions of biosurfactants for ruminants}

Compared with synthetic surfactants, biosurfactants are the natural choice as they possess a lot of advantages, such as stability, excellent efficiency, lower toxicity and biodegradability at a wide range of $\mathrm{pH}$ and temperature values (Banat et al., 2010). For example, the biosurfactant produced by Rhodococcus sp. strain TA6 was stable during exposure to high salinity $(10 \% \mathrm{NaCl})$, elevated temperatures $\left(120^{\circ} \mathrm{C}\right.$ for $\left.15 \mathrm{~min}\right)$ within a wide $\mathrm{pH}$ range 


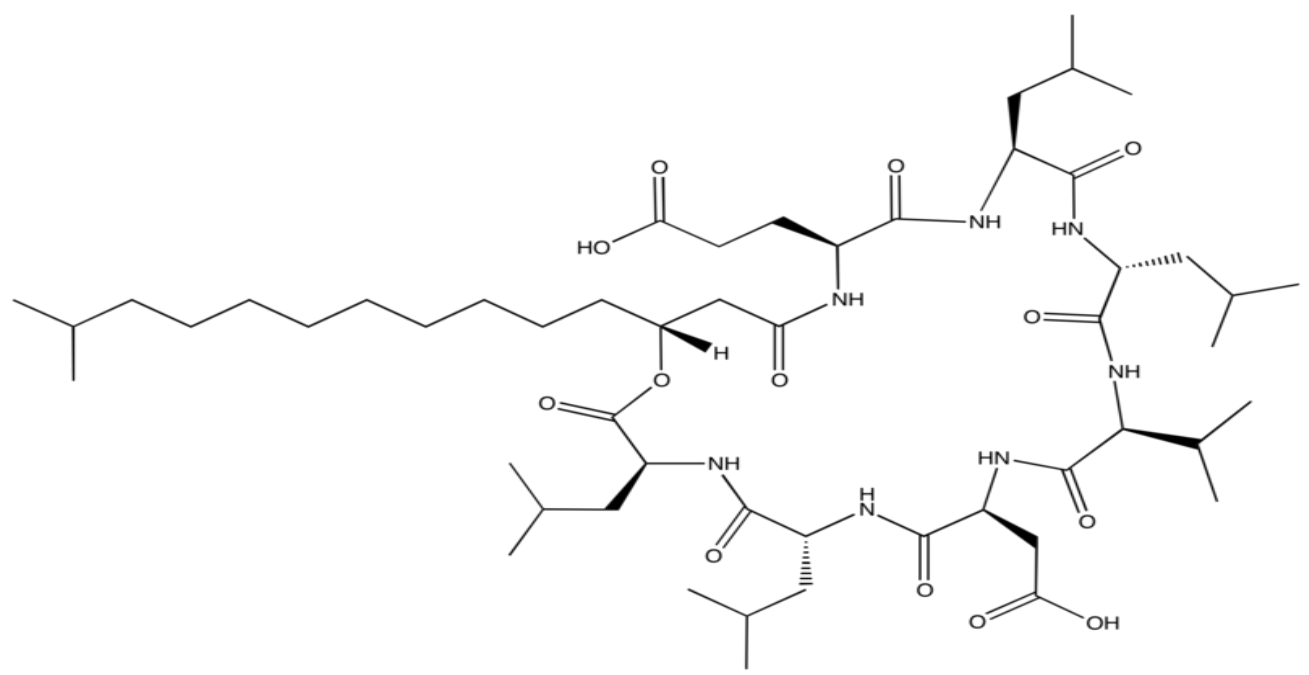

Figure 2. Structure of the surfactin synthesized by Bacillus subtilis.

(4.0 10.0) as well as was capable of forming stable emulsions with various hydrocarbons ranging from pentane to light motor oil (Shavandi et al., 2011). Another biosurfactant, mannoprotein, which was extracted from the cell walls of Kluyveromyces marxianus, formed emulsions that were stable for 3 months when subjected to a wide range of $\mathrm{pH}(3 \sim 11)$ and $\mathrm{NaCl}$ concentrations (2 50 $\mathrm{g} / \mathrm{L}$ ) at a concentration of $12 \mathrm{~g} / \mathrm{L}$ (Lukondeh et al., 2003). The lipopepetide surfactin (Figure 2) from Bacillus subtilis can significantly reduce surface tension of water from 72 to $27 \mathrm{mN} / \mathrm{m}$ at a concentration as low as $20 \mu \mathrm{M}$ (Tsan et al., 2007; Yeh et al., 2005). A lipopeptide secreted by Selenomonas ruminantium showed high surface tension reduction $(25.5 \mathrm{mN} / \mathrm{m})$, a low critical micelllar concentration $(8 \mathrm{mg} / \mathrm{l})$, thermal and $\mathrm{pH}$ stability with respect to surface tension reduction and emulsification activity, and a high level of salt tolerance (Saimmai et al., 2012). Generally speaking, lipopeptides lower the surface tension more than glycolipids, because of the specific structure of lipopeptides which have a hydrophilic part that contains polar amino acids and the hydrophobic part that contains lipophilic fatty acids and non-polar amino acids, and that may give rise to its antagonistic activity against various pathogenic fungi (Janek et al., 2010).

At present, the interest of microbial biosurfactant research is mainly focused on their biological mechanism, such as regulating the structure of cell membrane, carrier functions and antimicrobial functions. Lipopeptides as the biosurfactants with antimicrobial activity have been frequently reported (Banat et al., 2010). Some lipopeptides have been extensively studied, such as surfactin, fengycin, iturin, bacillomycins and mycosubtilins produced by Bacillus subtilis (Vater et al., 2002), lichenysin, pumilacidin and polymyxin $B$ are other antimicrobial lipopeptides produced by $B$. licheniformis, B. pumilus and B. polymyxa, respectively. The amphiphilic nature of surfactin was beneficial to form the ion channel of cell membrane (Grau et al., 1999). Inhibiting the growth of pathogenic bacteria in the gastrointestinal tract is one of the main mechanisms for lipopeptides secreted by Bacillus (Hong et al., 2005).

Addition of yeast culture containing emulsified glycolprotein to diets of ruminants increased the digestibility of $\mathrm{OM}$, crude protein and hemicellulose, and improved the population of ruminal cellulolytic bacteria as well as the rate of acetic acid and propionic acid production (Wiedmeier et al., 1987). The culture of single strains with rhamnolipid demonstrated that the rhamnolipid increased the numbers of fungi, enhanced xylanase activity as well as improved degradation of cellulose and hemicellulose, but inhibited the protease production (Zeng et al., 2006; Ganesh et al., 2008). On the basis of other reports in the literatures, stabilization of cellulase activity was ascribed to reducing denaturation of enzyme at the air-liquid interface, due to the surfactant's effectiveness on excluding enzyme from the interface (McAllister et al., 2000). Biosurfactants which have an excellent emulsifying property also play an important role in the adsorption and desorption processes at the liquid-solid interface, for example, by participating in the physiological process of bacteria pathogenicity, quorum sensing and membrane biosynthesis. At the same time, bioemulsifier covered the surface of microbes can transfer from the adjacent bacteria to another one (Ron and Rosenberg, 2001), and it is easier for microbial flora to move by secreting surface active substances to reduce the surface tension of liquid (Kearns, 2010). A study suggested that bacteria can secrete a biosurfactant to form a regulatory biological membrane, which could stimulate the adhesion of specific microbial community, whereas inhibit the adhesion of competitive flora (Neu, 1996). Dirhamnolipids are microbial biosurfactants produced by Pseudomonas spp. that 
have a large polar head group and a smaller hydrophobic portion that behaves as an inverted-cone shaped molecule, increasing motional disorder of the phospholipid acyl chains and dehydration of aqueous interface. It has been proposed that this might delay its disruptive effects on membranes by conferring positive curvature to membranes (Ortiz et al., 2010). The dirhamnolipid is thought to behave as an inverted-cone-shaped molecule because phosphatidylethanolamine group stimulates dirhamnolipids to bind with each other, whereas lysophosphatidylcholine opposes this binding (Aranda et al., 2007). It could be concluded that bacteria, by secreting biosurfactant or bioemulsifier, can alter the interaction between the surface characteristics and environmental conditions. Along with the development of the technology on the biosurfactants, one can easily predict that research and application of biosurfactants on animal nutrition can go even further.

\section{CONCLUSION}

The studies of synthetic surfactants on the animal nutriation are getting more and more attractive. Some surfacetants including Tween series, SOLFA-850, sorbitan trioleate and APG, have been proven to have many practical applications for regulating rumen fermentation, improving the nutritive value of feedstuffs and productivity as well as reducing feeding costs. With increasing societal emphasis on environmentally sensitive farming on safety of food supply, synthetic surfactants will face more and more challenges as animal feed additives. Therefore, ruminant nutrition researchers should be ready to exploit biosurfactants, whose broad structural diversities and environmental friendliness to make them candidates to replace synthetic surfactants.

This article suggests that future researches and application should pay more attention to the following aspects. Firstly, researchers should address the fundamental research and application of biosurfactants, including preparation and purification technology, mechanisms of action, application mode and safety evaluation. Secondly, studies should be carried out on producing high-yield strains and improving fermentation technology. High yield microbial strains should be screened, separated and purified by mutation and genetic engineering to produce biosurfactants with high efficiency and security. Thirdly, research should be conducted on producing biosurfactants from organic renewable resources, if such materials have the potential to reduce production costs.

\section{ACKNOWLEDGEMENTS}

We offer our sincerest gratitude to the Natural Science Foundation of China (No. 31172234) and the pilot special funds of Chinese Academy of Sciences (XDA05020700) for supporting, and we also thanks Chuanshe Zhou and Xuefeng Han, who give us some valuable advices and helpful assistance.

\section{Author contributions}

The work presented here was carried out in collaboration between all authors including Yong Liu, Shaoxun Tang, Ziliang Tan and A.Z.M. Salem defined the research theme. Yong Liu consulted, collected and analyzed the document literatures, designed the article structures, and wrote the manuscript. Shaoxun Tang participated in the modification and processing as well as adjustment the structure. Ziliang Tan and A.Z.M. Salem were charged for the total design and modification as well as confirmed the final draft.

\section{REFERENCES}

Abdel-Mawgoud A, Lépine F, Déziel E (2010). Rhamnolipids: diversity of structures, microbial origins and roles. Appl. Environ. Microbiol., 86:1323-1336.

Amaral PFF, Lehocky M, Barros-Timmons AMV, Rocha-Leão MHM, Coelho MAZ, Coutinho JAP (2006). Cell surface characterization of Yarrowia lipolytica IMUFRJ 50682. Yeast, 23:867-877.

Aranda FJ, Espuny MJ, Marqués A, Teruel JA, Manresa Á, Ortiz A (2007). Thermodynamics of the interaction of a dirhamnolipid biosurfactant secreted by Pseudomonas aeruginosa with Phospholipid Membranes. Langmuir, 23:2700-2705.

Banat I, Franzetti A, Gandolfi I, Bestetti G, Martinotti M, Fracchia L, Smyth T, Marchant R (2010). Microbial biosurfactants production, applications and future potential. Appl. Environ. Microbiol., 87:427444.

Börjesson J, Engqvist M, Sipos B, Tjerneld F (2007). Effect of poly (ethylene glycol) on enzymatic hydrolysis and adsorption of cellulase enzymes to pretreated lignocellulose. Enzyme Microb. Technol., 41:186-195.

Castanon M, Wilke CR (1981). Effects of the surfactant tween 80 on enzymatic hydrolysis of newspaper. Biotechnol. Bioeng., 23: 13651372.

Chen Y, Zhang H, Wang H, Yang K (2011). Effects of dietary addition of non-ionic surfactants on ruminal metabolism and nutrient digestion of chinese merino sheep. Asian J. Anim. Vet. Adv., 6:688-696.

Cong ZH, Tang SX, Tan ZL, Sun ZH, Zhou CS, Han XF, Wang M, Ren GP (2009). Effects of different nonionic surfactants on in vitro fermentation characteristics of cereal straws. J. Anim. Sci., 87:10851096.

D'Aes J, Maeyer KDe, Pauwelyn E, Höfte M (2010). Biosurfactants in plant-Pseudomonas interactions and their importance to biocontrol. Environ. Microbiol. Rep., 2:359-372.

de Bruijn I, Raaijmakers JM (2009). Regulation of cyclic lipopeptide biosynthesis in Pseudomonas fluorescens by the ClpP Protease. J. Bacteriol., 191:1910-1923.

Demain AL (1968). Regulatory mechanisms and the industrial production of microbial metabolites. Lloydia, 395-418.

Deng, WD, Xi DM, Mao HM (2005). As a neotype feed addictive,effects of tween-80 on the rumen ecosystem and productivity of ruminant. Feed Industry of Chinese, 26:7-13.

Eriksson T, Börjesson J, Tjerneld F (2002). Mechanism of surfactant effect in enzymatic hydrolysis of lignocellulose. Enzyme Microb. Technol., 31:353-364.

Franzetti A, Gandolfi I, Bestetti G, Smyth TJP, Banat IM (2010). Production and applications of trehalose lipid biosurfactants. Eur. J. Lipid Sci. Technol., 112:617-627.

Ganesh KA, Venkatesan R, Kirubagaran R, Prabhakar T, Sekaran G (2008). Effects of nonionic surfactant on hydrolysis and fermentation of protein rich tannery solid waste. Biodegrad., 19:739-748. 
Gashe BA (1992). Cellulase production and activity by Trichoderma sp. A-001. J. Appl. Microbiol., 73:79-82.

Grau F, Almela P, Aparisi L, Bautista D, Pascual I, Peña A, Rodrigo J (1999). Usefulness of alanine and aspartate aminotransferases in the diagnosis of microlithiasis in idiopathic acute pancreatitis. Int. J. Gastrointest. Cancer., 25: 107-111.

Gurjar M, Khire JM, Khan MI (1995). Bioemulsifier production by Bacillus stearothermophilus VR-8 isolate. Lett. Appl. Microbiol., 21: 83-86.

Gyu-Chul A, Jeong-Hoon K, Eun-Kyu P, Young-Kyoon O, Gang-Yeon L, Jung-II L, Chong-Min K, Keun-Kyu P (2009). Effects of non-ionic surfactant supplementation on ruminal fermentation, nutrient digestibility and performance of beef steers fed high-roughage diets. Asian Australas. J. Anim. Sci., 22:1011-2367.

Holmberg K, Jönsson B, Kronberg B, Lindman B (2003). Intermolecular Interactions. In Surfactants and Polymers in Aqueous Solution,. John Wiley \& Sons, Ltd. pp.157-174.

Hong HA, Duc LH, Cutting SM (2005). The use of bacterial spore formers as probiotics. FEMS Microbiol. Rev., 29:813-835.

Isolation and analysis of lipopeptides and high molecular weight biosurfactants. In Handbook of Hydrocarbon and Lipid Microbiology, ed. K. N. Timmis. Springer Berlin Heidelberg. ,pp. 3687-3704.

Janek T, Lukaszewicz M, Rezanka T, Krasowska A (2010). Isolation and characterization of two new lipopeptide biosurfactants produced by Pseudomonas fluorescens BD5 isolated from water from the Arctic Archipelago of Svalbard. Bioresour. Technol., 101: 6118-6123.

Kamande GM, Baah J, Cheng KJ, McAllister TA, Shelford JA (2000). Effects of tween 60 and tween 80 on protease activity, thiol group reactivity, protein adsorption, and cellulose degradation by rumen microbial enzymes. J. Dairy Sci., 83:536-542.

Käppeli O, Finnerty WR (1980). Characteristics of hexadecane partition by the growth medium of Acinetobacter sp. Biotechnol. Bioeng., 22:495-503.

Kearns DB (2010). A field guide to bacterial swarming motility. Nat. Rev. Micro., 8:634-644.

Kim CH, Kim JN, Ha JK, Yun SG, Lee SS (2004). Effects of dietary addition of surfactant Tween 80 on ruminal fermentation and nutrient digestibility of Hanwoo steers. Asian Australas. J. Anim. Sci., 17:337342.

Kim H, Kim S, Kim C (2007). The effects of nonionic surfactants on the pretreatment and enzymatic hydrolysis of recycled newspaper. Biotechnol. Bioprocess Eng., 12:147-151.

Kim MH, Lee SB, Ryu DDY, Reese ET (1982). Surface deactivation of cellulase and its prevention. Enzyme Microb. Technol., 4:99-103.

Kim W, Gamo Y, Yahaya MS, Yimiti W, Goto M (2005). Pretreatment of surfactant Tween 80 and fibrolytic enzyme influencing volatile fatty acid and methane production of a total mixed ration by mixed rumen microorganisms at in vitro. Grassland Sci., 51:145-152.

Kumar SS, Neelam K (2009). Effect of non-ionic surfactant (tween 80) on rumen microbial enzymes. Indian J. Anim. Nutr., 26:233-238.

Kurakake M., Ooshima H, Kato J, Harano Y (1994). Pretreatment of bagasse by nonionic surfactant for the enzymatic hydrolysis. Biores. Technol., 49:247-251.

Lee SS, Ahn BH, Kim HS, Kim CH, Cheng KJ, Ha JK (2003). Effects of non-ionic surfactants on enzyme distributions of rumen contents, anaerobic growth of rumen microbes, rumen fermentation characteristics and performances of lactating cows. Asian-Autral. Associ. Anim. Pro. Soc. pp. 104-115.

Lee SS, Kim HS, Moon YH, Choi NJ, Ha JK (2004). The effects of a non-ionic surfactant on the fermentation characteristics, microbial growth, enzyme activity and digestibility in the rumen of cows. Anim. Feed Sci. Technol., 115:37-50.

Li AH, Xu MY, Sun W, Sun GP (2011). Rhamnolipid production by Pseudomonas aeruginosa GIM 32 using different substrates including molasses distillery wastewater. Appl. Biochem. Biotechnol., 163:600-611.

Liu J, Shi J, Li J, Yuan X (2011). Effects of surfactants tween 80 and rhamnolipid on the extracellular enzymes amylase, protease, CMCase and xylanase of one strain. Int. Conf. Comput. Distrib. Control Intelligent Environ. Monit., 1207-1210.

Long K., Knapp JS (1991). The effect of junlon PW110 and tween 80 on the production of cellulolytic enzymes by Coprinus cinereus. Mycol.
Res., 95:1077-1081.

Lukondeh T, Ashbolt N, Rogers P (2003). Evaluation of Kluyveromyces marxianus FII 510700 grown on a lactose-based medium as a source of a natural bioemulsifier. J. Ind. Microbiol. Biotechnol., 30:715-720.

Maneerat S, Nitoda T, Kanzaki H, Kawai F (2005). Bile acids are new products of a marine bacterium, Myroides sp. strain SM1. Appl. Environ. Microbiol., 67:679-683.

McAllister TA, Stanford K, Bae HD, Treacher RJ, Hristov AN, Baah J, Shelford JA, Cheng KJ (2000). Effect of a surfactant and exogenous enzymes on digestibility of feed and on growth performance and carcass traits of lambs. Can. J. Anim. Sci., 80:35-44.

Neu T (1996). Significance of bacterial surface-active compounds in interaction of bacteria with interfaces. Microbiol. Rev., 60:151-166.

Olsen SN, Bohlin C, Murphy L, Borch K, McFarland KC, Sweeny MD, Westh $P$ (2011). Effects of non-ionic surfactants on the interactions between cellulases and tannic acid: A model system for cellulasepoly-phenol interactions. Enzyme Microb. Technol., 49:353-359.

Ortiz A, Aranda F, Teruel J (2010). Interaction of dirhamnolipid biosurfactants with phospholipid membranes: a molecular level study. Adv. Exp. Med. Biol., 672:42-53.

Pardo A (1996). Effect of surfactants on cellulase production by Nectria catalinensis. Curr. Microbiol., 33:275-278.

Park, Won J, Takahata, Yasuyuki, Kajiuchi, Toshio, Akehate, Takashi (1992). Effects of nonionic surfactant on enzymatic hydrolysis of used newspaper. Biotechnol. Bioeng., 39:117-120.

Radmacher E, Alderwick LJ, Besra GS, Brown AK, Gibson KJC, Sahm $H$, Eggeling $L$ (2005). Two functional FAS-I type fatty acid synthases in Corynebacterium glutamicum. Microbiol., 151:2421-2427.

Reznik G, Vishwanath P, Pynn M, Sitnik J, Todd J, Wu J, Jiang Y, Keenan B, Castle A, Haskell R, Smith T, Somasundaran P, Jarrell $K$ (2010). Use of sustainable chemistry to produce an acyl amino acid surfactant. Appl. Environ. Microbiol., 86:1387-1397.

Ron EZ, Rosenberg E (2001). Natural roles of biosurfactants. Environ. Microbiol., 3:229-236.

Rosen MJ, Kunjappu JT (2012). Surfactants and interfacial phenomena (4th ed.). ed. John Wiley and Sons, 1. Hoboken, New Jersey.

Rufino RD, Sarubbo LA, Campos-Takaki GM (2007). Enhancement of stability of biosurfactant produced by Candida lipolytica using industrial residue as substrate. World J. Microb. Biot., 23:729-734.

Saerens KMJ, Saey L, Soetaert W (2011). One-step production of unacetylated sophorolipids by an acetyltransferase negative Candida bombicola. Biotechnol. Bioeng., 108:2923-2931.

Saimmai A, Onlamool T, Sobhon V, Maneerat S (2012). An efficient biosurfactant-producing bacterium Selenomonas ruminantium CT2, isolated from mangrove sediment in south of Thailand. World $\mathrm{J}$. Microbiol. Biotechnol. 29:87-102.

Seydlová G, Svobodová J (2008). Review of surfactin chemical properties and the potential biomedical applications. Cent. Eur. J. Med., 3:123-133.

Shavandi M, Mohebali G, Haddadi A, Shakarami H, Nuhi A (2011). Emulsification potential of a newly isolated biosurfactant-producing bacterium, Rhodococcus sp. strain TA6. Colloids Surf., B, 82:477482.

Shelford JA, Cheng KJ, Kamande GM (1996). Enzyme enhancers: the key to unlocking the energy from feed. Western Canadian Dairy Seminar, 8:269-275.

Smyth TJP, Perfumo A, McClean S, Marchant R, Banat IM (2010).

Soberón-Chávez G, Maier R (2011). Biosurfactants: a general overview biosurfactants. ed. pp.1-12. G. Soberón-Chávez, 1-11. Springer Berlin/Heidelberg.

Sperling RA, Parak WJ (2010). Surface modification, functionalization and bioconjugation of colloidal inorganic nanoparticles. Philosophical Transactions of the Royal Society A: Mathematical, Physical and Engineering Sciences, 368:1333-1383.

Thavasi R, Jayalakshmi S, Balasubramanian T, Banat IM (2007). Biosurfactant production by Corynebacterium kutscheri from waste motor lubricant oil and peanut oil cake. Lett. Appl. Microbiol., 45:68691.

Tsan P, Volpon L, Besson F, Lancelin JM (2007). Structure and dynamics of surfactin studied by NMR in micellar media. J. Am. Chem. Soc., 129:1968-1977.

Tu M, Pan X, Saddler JN (2009). Adsorption of cellulase on cellulolytic 
enzyme lignin from lodgepole pine. J. Agric. Food. Chem., 57:7771 7778.

Vater J, Kablitz B, Wilde C, Franke P, Mehta N, Cameotra SS (2002). Matrix-assisted laser desorption ionization-time of flight mass spectrometry of lipopeptide biosurfactants in whole cells and culture filtrates of Bacillus subtilis C-1 Isolated from petroleum sludge. Appl. Environ. Microbiol., 68: 6210-6219.

Viparelli P, Alfani F, Cantarella M (2001). Experimental validation of a model for [alpha]-chymotrypsin activity in aqueous solutions of surfactant aggregates. J. Molecular Catalysis B: Enzymatic, 15:1-8.

Wang C, Mahrous EA, Lee RE, Vestling MM, Takayama K (2011). Novel Polyoxyethylene-Containing Glycolipids Are Synthesized in Corynebacterium matruchotii and Mycobacterium smegmatis Cultured in the Presence of Tween 80. J. Lipids, 2011:1-12.

Wiedmeier RD, Arambel MJ, Walters JL (1987). Effect of yeast culture and Aspergillus oryzae fermentation extract on ruminal Characteristics and Nutrient Digestibility. J. Dairy Sci., 70:2063-2068.

Wittenberger CL, Beaman AJ, Lee LN (1978). Tween 80 effect on glucosyltransferase synthesis by streptococcus salivarius. J. Bacteriol., 133:231-239.

Yeh MS, Wei YH, Chang JS (2005). Enhanced Production of Surfactin from Bacillussubtilis by addition of solid carriers. Biotechnol. Progr., 21: 1329-1334.
Yuan ZQ, Tang SX, Zeng B, Wang M, Tan ZL, Sun ZH, Zhou CS, Han XF, Bamikole MA (2010). Effects of dietary supplementation with alkyl polyglycoside, a nonionic surfactant, on nutrient digestion and ruminal fermentation in goats. J. Anim. Sci, 88:3984-91.

Zaragoza A, Aranda FJ, Espuny MAJ, Teruel JA, Marqués A, Manresa AN, Ortiz A (2009). Mechanism of membrane permeabilization by a bacterial trehalose lipid biosurfactant produced by Rhodococcus sp. Langmuir, 25:7892-7898.

Zeng B, Tan ZL, Zeng JY, Tang SX, Tan CY, Zhou CS, Han XF, Zhong $R Z$ (2012). Effects of dietary non-ionic surfactant and forage to concentrate ratio on bacterial population and fatty acid composition of rumen bacteria and plasma of goats. Anim. Feed Sci. Technol. 173:167-176.

Zeng GM, Shi JG, Yuan XZ, Liu J, Zhang ZB, Huang GH, Li JB, Xi BD, Liu HL (2006). Effects of Tween 80 and rhamnolipid on the extracellular enzymes of Penicillium simplicissimum isolated from compost. Enzyme Microb. Technol., 39:1451-1456. 